\title{
"A Research on Developing Managerial skills through Management Education among Management Graduates at selected Institutes in Pune and Mumbai"
}

\author{
Archana Salve
}

\begin{abstract}
Globalization of Industrial sector is changing the relationship between management education and industrial sector .Top business schools in India have everything going for them in terms of large infrastructure, fair number of faculty, good placements and industry support. But for rest of the industry running business schools is an adventure. Taking students of weaker background and polishing them into industry- savvy MBAs is a challenge.

For these MBA institutes their still remains a gap between what industries expect and what is taught in academic institutes .This research study is aimed at knowing the actual scenario of management education today as far as quality of education and managerial skills development in students is concerned
\end{abstract}

\section{INTRODUCTION}

Globalization of Industrial sector is changing the relationship between management education and industrial sector .Top business schools in India have everything going for them in terms of large infrastructure, fair number of faculty, good placements and industry support. But for rest of the industry running business schools is an adventure. Taking students of weaker background and polishing them into industry- savvy MBAs is a challenge.

For these MBA institutes their still remains a gap between what industries expect and what is taught in academic institutes. This research study is aimed at knowing the actual scenario of management education today as far as quality of education and managerial skills development in students is concerned

\section{OBJECTIVES OF THE STUDY:}

In this era of globalization ,competition and industrialization the students in management streams face new challenges and need good quality education to become successful managers entrepreneurs. Also there is major impact of recession on the various industrial sectors in India.

For these reasons Management Institutes in India need to upgrade and stand the test of time for present scenario .The main purpose of this research is to find out what is present status of Management education

1.To study overall impact of Management Education in

Revised Version Manuscript Received on 10, September 2019.

Dr. Archana Salve, Associate Professor \& Head of Department, Indira College of Engineering and Management, Pune,Maharastra, India.(Email: archanasalve13@gmail.com) developing Managerial skills in Management students.

2.To study the learning outcomes in students passing from Management Institutes in Pune and Mumbai region.

3.To study the applicability of today's Management curriculum in grooming students' ability of decision making, analytical skill and crisis handling skill.

4.To study Industry-Institute Participation in enhancing Leadership, Motivational and communication skills.

5.To study the status of Autonomous and University affiliated institutes curriculum and its modus of operandi in enhancing managerial Skills.

\section{RESEARCH METHODOLOGY}

Type of research:

This is a Quantitative type of research. Quantitative research is based on précised measurements using structured and validated data collection instrument . It is used to test hypotheses, look at cause and effect and make predictions .In this study selected Management institutes from Pune and Mumbai regions are involved .specific number of students and faculty members are respondents for the study .In Quantitative research generalizable findings can be applied to other populations

\section{Sample Design: -}

The study is carried out by considering Stratified Random Sampling method .This type of sampling method works well for population with variety of attributes. Selected institutes from Pune \& Mumbai region both Autonomous as well as University affiliated institutes have been involved in the research

\section{Universe:}

Total number of Autonomous institutes in Pune is $\mathbf{2 9}$ and total number of University affiliated institutes in Pune is 178. Management institutes in Mumbai region - Total number of Autonomous institutes in Mumbai is $\mathbf{2 3}$ and total number of University affiliated institutes in Mumbai region is $\mathbf{7 9}$.

Total Population of research study is $\mathbf{3 0 0 0 0}$. 


\section{Sample size:}

In this research study 20 institutes from Pune region and 18 institutes from Mumbai region have been involved in this study .Total number of respondents from Pune region including Autonomous institutes in Pune and University affiliated institutes in Pune is $\mathbf{6 6 0}$ and Total number of respondents from Mumbai region including Autonomous institutes in Mumbai and University affiliated institutes in Mumbai is 659

Table No Sample Composition

\begin{tabular}{|c|c|c|c|c|}
\hline $\begin{array}{l}\text { St } \\
\text { oo }\end{array}$ & Respeadents & Shadents & Faculty & Total \\
\hline 1 & $\begin{array}{l}\text { Autenomous institutes of } \\
\text { Pune }\end{array}$ & 198 & 128 & 326 \\
\hline 2 & $\begin{array}{l}\text { University affitiated } \\
\text { institutes of Pume }\end{array}$ & 204 & 130 & 334 \\
\hline 3 & $\begin{array}{l}\text { Autenomous institutes of } \\
\text { Mumbui }\end{array}$ & 197 & 130 & 327 \\
\hline \multirow[t]{2}{*}{4} & $\begin{array}{l}\text { University affilizted } \\
\text { institutes of Mombai }\end{array}$ & 205 & 127 & 332 \\
\hline & Total & 504 & 515 & 1319 \\
\hline
\end{tabular}

Total number of respondents in Mumbai and Pune regions is $\mathbf{1 3 1 9}$.

\section{Sources of Data :}

\section{Primary Data}

Primary Data is collected by questionnaire method, using closed ended \& descriptive type of questions. Students of first \& second year MBA \& faculty members are the respondents.

\section{Secondary data Collection:}

Secondary data is collected from management's journals, newspapers, Books, Magazines, internet, B school survey, websites etc. Also previous surveys on this topic are taken into consideration.

\section{Designs of questionnaires:}

Researcher has used two different questionnaires one for students \& other for faculty members . The scaling is done using Likert scale .

\section{Questionnaire for Student respondents:}

This is a structured questionnaire with closed ended question to avoid the variations in response of the respondents. All questions are given sufficient options to record the replies of the respondents. This style of questionnaires is adopted to standardize the responses. Total 23 questions having multiple sub questions are designed in order to get thorough information regarding Students development in MBA institutes. All the questions asked in this questionnaire were formulated based on intensive and extensive literature review ,experts opinions and pilot survey

\section{Questionnaire for faculty members:-}

This is also a structured questionnaire with close ended questions to avoid the variations in responses of the respondents. All questions are given sufficient options to record the replies of respondents. This style of questionnaire is adopted to standardize the response. Total 28 questions having multiple sub questions are designed to get through information regarding quality of education in respective management institutes. All the questions asked in this questionnaire were formulated based on intensive and extensive literature review ,experts opinions and pilot survey .

\section{DATA ANALYSIS :-}

After collection of primary \& secondary data processing of data was done by following operations.

Data analysis has been done in two parts.

A) Data Analysis for student respondents.

B)Data analysis for faculty member respondents.

1. Editing - To facilitate data entry , coding and tabulation of data, it has been scrutinized in detail.

2. Coding: - It is a process of assigning numerals \& symbols to answers so that responses can be put into limited number of categories. Coding is done for efficient analysis and through it the several replies reduced to small number of classes.

3. Tabulation: - When mass data collected assembled, it became necessary for the researcher to arrange the same in some kind of concise and logical order in the form of tabulation i.e the data is orderly arranged in columns and rows .Researcher summarized raw data and displayed in compact form for data analysis .

\section{Tools used for Data Analysis :}

One way ANOVA test \& Friedman Chi-square test are used to know the difference in various parameters across four groups of institutes (Autonomous institutes of Pune, University affiliated institutes of Pune, Autonomous institutes of Mumbai \& University affiliated institutes of Mumbai).

One way ANOVA test is a parametric test used to determine whether there are any significant difference between three or more independent groups.

Friedman chi- square test is a nonparametric test . it is used to detect differences in treatments across multiple test attempts. This procedure involves ranking each row or block together, then considering the values of ranks by columns .

Multiple response analysis and cluster bar chart is also used for presentation of data analysis.

\section{USE OF COMPUTER SOFTWARE IN DATA ANALYSIS \& RESULTS}

1) IBM SPSS 20 updated version (Statistical package for social science) is used for data analysis.

2) Microsoft office excel is used for data entry.

Limitations of research :-

The research is carried out in Mumbai \& Pune regions, hence the various parameters considered during research may or may not represent at different places other than these two regions.

1. All MBA Institutes in Pune and Mumbai region cannot be covered in this study. 
2. Complete data collection by questionnaire method is difficult.

3. Only selected Institutes will represent in this study.

Problem faced during research

1)Difficulty in approaching respondents as data collection was done during working hours of colleges.

2) Respondents were reluctant to share some information asked in the questionnaires.

\section{Hypotheses of testing :-}

Communications skills:

Test : One way Anova

\begin{tabular}{|c|c|c|}
\hline Statisocal test & Statistical resslts & Conclusiva \\
\hline One पay - ANOVA & Wedch $(3,388)=184 \quad P=0.00$ & Nill hypotheses is rejected \\
\hline
\end{tabular}

Conclusion: Thus it can be concluded that, Communication skills development is better in student's Autonomous institutes in Pune and Mumbai and University affiliated institutes in Mumbai than University affiliated institutes in Pune.

Motivation skills :

Test : One way ANOVA

\begin{tabular}{|c|c|c|}
\hline Satistical test & Statistical results & Conclusinn \\
\hline One way -ANOWA & Wedd $(3,325)=117 .+p=0.00$ & NuIl hypotheses is rejacted \\
\hline
\end{tabular}

Conclusion: Thus it can be concluded that Motivational skills development is better in Autonomous institutes in Mumbai and Pune than University affiliated institutes in Mumbai and Pune.

Analytical and Logical skills :

Test :One Way -ANOVA

\begin{tabular}{|c|c|c|}
\hline Statisfical test & Statistical results & Conchsina \\
\hline One rzy -ANOVA & Welch $(3,413)=475 \quad P=0.00$ & Nill hypothese is rejected \\
\hline
\end{tabular}

Conclusion : Thus it can be concluded that, analytical and logical skills development is better in University affiliated institutes in Mumbai and Pune than Autonomous institutes in Pune and Mumbai.

Crisis Management skills

Test : One Way -ANOVA

\begin{tabular}{|c|c|c|}
\hline Statistical test & Safistical results & Couchusiva \\
\hline One $\overline{Q Z Y}$-ANOTA & Walch $(3,247)=543 \quad P=f: 00$ & Null hypotheses is rjected \\
\hline
\end{tabular}

Conclusion: Thus it is concluded that Crisis management skills development in students of Autonomous institutes of Pune is best followed by Autonomous institutes of Mumbai which have done better than University affiliated institutes of Pune and Mumbai.

Leadership skills :

Test : One Way -ANOVA

\begin{tabular}{|l|l|l|}
\hline Statisical test & Safistical results & Condusinu \\
\hline Ore war-ANOVA & $\begin{array}{l}\text { Welch }(3,156)=114 \quad \mathrm{P}= \\
0.00\end{array}$ & Null hypothese is rejectad \\
\hline
\end{tabular}

Conclusion : Thus it can be concluded that, Leadership skill development is better in Autonomous institutes in Pune and Mumbai than university affiliated institutes in Pune and Mumbai.

Innovative skills:

Test : One -Way ANOVA

\begin{tabular}{|c|c|c|}
\hline Statiscal test & Statistical results & Conchssion \\
\hline One ray -ANOVA & $\begin{array}{l}\text { Walch }(3,24.8)=3649 \\
p=0.00\end{array}$ & Null hypotheses is rejected \\
\hline
\end{tabular}

Conclusion: Thus it can be concluded that innovative skills development is better in Autonomous institutes in Pune than Autonomous institutes in Mumbai, university affiliated institutes in Mumbai and Pune.

Decision making Skills:

Test : One Way ANOVA

\begin{tabular}{|l|l|l|}
\hline Purpose & Satistical resals & Conclusion \\
\hline One way - ANOWA & Wetch $(3,257)=55 \quad \mathrm{P}=0.00$ & Nul hypothese is rejected \\
\hline
\end{tabular}

Conclusion : Thus it can be concluded that, Decision making skills development is better in Autonomous institutes in Mumbai than Autonomous institutes in Pune, University affiliated institutes in Mumbai and Pune.

Managerial skills development in students of Autonomous institutes of Pune and Mumbai is better than University affiliated institutes of Mumbai and Pune.

Thus the hypothesis is tested and validated .

\section{Learning Outcome:}

Test: One way ANOVA

\begin{tabular}{|l|l|l|}
\hline Statistical test & Statistical results & $\begin{array}{l}\text { Null accepted } \\
\text { rejected }\end{array}$ \\
\hline One way -ANOVA & $\begin{array}{l}\text { Welch }(3,274.7)=72.66 \\
\mathrm{p}=0.00\end{array}$ & $\begin{array}{l}\text { Null hypotheses is } \\
\text { rejected }\end{array}$ \\
\hline
\end{tabular}

Conclusion : Learning outcomes of students in autonomous institutes of Pune and Mumbai are better than students of University affiliated institutes of Mumbai and Pune

Thus the hypothesis is tested and validated

Faculty Competence

Test : One Way ANOVA

\begin{tabular}{|l|l|l|}
\hline Statistical Test & Statistical results & $\begin{array}{l}\text { Null hypothesis is } \\
\text { accepted rejected }\end{array}$ \\
\hline One way - ANOVA & $\begin{array}{l}\text { Welch }(3,409.247) \\
9.038 \quad \mathrm{P}=0.00\end{array}$ & $\begin{array}{l}\text { Null bypotheses is } \\
\text { rejected }\end{array}$ \\
\hline
\end{tabular}

Conclusion : Thus it can be concluded that University affiliated institutes of Mumbai, Autonomous institutes of Mumbai and Pune are similar in performance in students perception of faculty competence and they have performed better than University affiliated institutes of Pune 
"A Research on Developing Managerial skills through Management Education among Management Graduates at selected Institutes in Pune and Mumbai"

Competitive Environment :

Test : One Way ANOVA

\begin{tabular}{|l|ll|l|}
\hline Statistical Test & \multicolumn{2}{|l|}{ Statistical results } & $\begin{array}{l}\text { Null hypothesis is } \\
\text { accepted rejected }\end{array}$ \\
\hline One way-ANOVA & $\begin{array}{l}\text { Welch }(3,406.2) \\
=19.277 \quad \mathrm{P}=0.00\end{array}$ & $\begin{array}{l}\text { Null hypotheses is } \\
\text { rejected }\end{array}$ \\
\hline
\end{tabular}

Conclusion: Thus it can be concluded that students' perception of competitive environment is better in University affiliated institutes in Mumbai, Autonomous institutes in Pune and Mumbai than University affiliated institutes in Pune.

Quality of Programmes :

Test : One Way ANOVA

\begin{tabular}{|l|l|l|}
\hline Statistical Test & Statistical results & $\begin{array}{l}\text { Null hypothesis is } \\
\text { accepted /rejected }\end{array}$ \\
\hline $\begin{array}{l}\text { One way }- \\
\text { ANOVA }\end{array}$ & $\begin{array}{l}\text { Welch }(3,410)= \\
131.050 \quad \mathrm{P}=0.00\end{array}$ & $\begin{array}{l}\text { Null hypotheses is } \\
\text { rejected }\end{array}$ \\
\hline
\end{tabular}

Conclusion: Thus it can be concluded that students' perception of quality of programmes is better in, Autonomous institutes in Pune and Mumbai than University affiliated institutes in Pune and Mumbai.

Personal Attention:

Test : : One Way ANOVA

\begin{tabular}{|l|l|l|}
\hline Statistical Test & Statistical results & $\begin{array}{l}\text { Null hypothesis is } \\
\text { accepted /rejected }\end{array}$ \\
\hline One way - ANOVA & $\begin{array}{l}\text { Welch }(3,389)=90,5 \\
\mathrm{P}=0.00\end{array}$ & $\begin{array}{l}\text { Null hypotheses is } \\
\text { rejected }\end{array}$ \\
\hline
\end{tabular}

Conclusion: Thus it can be concluded that Autonomous institutes in Pune gives more attention personally for students than university affiliated institutes in Pune and Mumbai and Autonomous institutes in Mumbai in present education system.

Faculty members with real world experience

Test : One Way ANOVA

\begin{tabular}{|l|l|l|}
\hline Statistical Test & Statistical results & $\begin{array}{l}\text { Null bypothesis is } \\
\text { accepted /rejected }\end{array}$ \\
\hline One way-ANOVA & $\begin{array}{l}\text { Welch }(3,383)=30.2 \\
p=000\end{array}$ & $\begin{array}{l}\text { Null hypotheses is } \\
\text { rejected }\end{array}$ \\
\hline
\end{tabular}

Conclusion: Thus it can be concluded that, there are more faculty members with real world experience in Autonomous institutes in Pune and Mumbai compared to university affiliated institutes in Pune and Mumbai.

Networking ties with business Community:

Test : : One Way ANOVA

\begin{tabular}{|l|l|l|}
\hline Statistical Test & Statistical results & $\begin{array}{l}\text { Null hypothesis is } \\
\text { accepted } \text { rejected }\end{array}$ \\
\hline One way - ANOVA & $\begin{array}{l}\text { Welch }(3,406)=129.4 \\
p=0.00\end{array}$ & $\begin{array}{l}\text { Null hypotheses is } \\
\text { rejected }\end{array}$ \\
\hline
\end{tabular}

Conclusion: Thus it can be concluded that It can be concluded that, there is more networking ties with business community in Autonomous institutes in Mumbai as compared to Autonomous institutes of Pune ,University affiliated institutes in Mumbai and Pune .
Improvement in skills and abilities:

Test : One way - ANOVA

\begin{tabular}{|c|c|c|}
\hline Purpose & Statistical results & Conclusina \\
\hline One Tray -ANOVA & $\begin{array}{l}\text { Welch }(3,345)=105.5 \mathrm{P}= \\
0.00\end{array}$ & Null hypothesis is regetered \\
\hline
\end{tabular}

Conclusion : Thus it can be concluded that, there is more improvement in skills and abilities of students in Autonomous institutes in Mumbai as compared to Autonomous institutes in Pune, University affiliated institutes in Mumbai and Pune.

Change in Personality Development in students :

Test: One way - ANOVA

\begin{tabular}{|c|c|c|}
\hline Purpose & Statistical results & Conclusion \\
\hline Ore $\mathrm{Wz}_{\mathrm{y}}$-ANONA & $\begin{array}{l}\text { Wedd }(3.112714)=123.89 p= \\
0.00\end{array}$ & Null hypothesis is räeted \\
\hline
\end{tabular}

Conclusion: Thus it can be concluded that; major development in personality is seen in MBA students of Autonomous institutes in Pune and Mumbai as compared to students of University affiliated institutes in Pune and Mumbai.

\section{Industry -Institute Participation:}

Test : One way - ANOVA

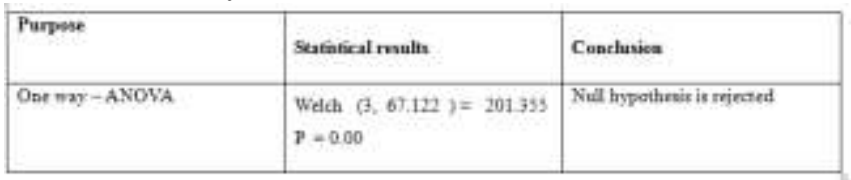

Conclusion: Thus it can be concluded that Autonomous institutes in Mumbai and Pune have done comparatively better than University affiliated institutes in Mumbai and Pune in industry institute partnership.

Communications skills:

Test : One way Anova

\begin{tabular}{|l|l|l|}
\hline Statistical test & Statistical results & Conclusion \\
\hline One way - ANOVA & $\begin{array}{l}\text { Welch }(3,388)=184 \\
\mathrm{P}=0.00\end{array}$ & $\begin{array}{l}\text { Null hypotheses is } \\
\text { rejected }\end{array}$ \\
\hline
\end{tabular}

Conclusion: Thus it can be concluded that, Communication skills development is better in student's Autonomous institutes in Pune and Mumbai and also in University affiliated institutes in Mumbai than University affiliated institutes in Pune.

Motivation skills :

Test : One way ANOVA

\begin{tabular}{|l|l|l|}
\hline Satitical tont & Statistical results & Conclusion \\
\hline One wyy - ANOVA & Wela $(3,325 \neq 117.4 p=0.00$ & Null hypotheses is recected \\
\hline
\end{tabular}


Conclusion: Thus it can be concluded that Motivational skills development is better in Autonomous institutes in Mumbai and Pune than University affiliated institutes in Mumbai and Pune.

Analytical and Logical skills:

Test : One Way -ANOVA

\begin{tabular}{|c|c|c|}
\hline Sativital iest & Satistical noults & Conchnsion \\
\hline Oareway-ANOVA & Wedch $(3,413)=475 \quad P=0.00$ & Sull hrpotases is rifected \\
\hline
\end{tabular}

Conclusion : Thus it can be concluded that, analytical and logical skills development is better in University affiliated institutes in Mumbai and Pune than Autonomous institutes in Pune and Mumbai.

Crisis Management skills :

Test : Test :One Way -ANOVA

\begin{tabular}{|c|c|c|}
\hline Statistical test & Sativikal renalis & Cuedusise \\
\hline $\operatorname{Can} w x y-A$ NOVA & Welch $(3,347-547 \quad D-0.00$ & Vull typotheum is rejected \\
\hline
\end{tabular}

Conclusion: Thus it is concluded that Crisis management skills development in students of Autonomous institutes of Pune is best followed by Autonomous institutes of Mumbai which have done better than University affiliated institutes of Pune and Mumbai.

Leadership skills :

Test : One Way -ANOVA

Conclusion : Thus it can be concluded that, Leadership skill development is better in Autonomous institutes in Pune and Mumbai than university affiliated institutes in Pune and Mumbai.

Innovative skills:

Test : One -Way ANOVA

Conclusion: Thus it can be concluded that innovative skills development is better in Autonomous institutes in Pune than Autonomous institutes in Mumbai, university affiliated institutes in Mumbai and Pune.

Decision making Skills:

Test : One Way ANOVA

\begin{tabular}{|c|c|c|}
\hline Pumpose & Statistical results & Cosclutina \\
\hline Oxe wzy -ANOVA & $\operatorname{Wedh}(3,257)=55 \quad P=000$ & Nut thypotheses is rejected \\
\hline
\end{tabular}

Conclusion : Thus it can be concluded that, Decision making skills development is better in Autonomous institutes in Mumbai than Autonomous institutes in Pune,

\begin{tabular}{|c|c|c|}
\hline Satentical tent & Sathifical reults & Conchasiea \\
\hline One way-ANOVA & $\begin{array}{l}\text { welch }(3,156)=114 \quad \mathrm{P}= \\
0.00\end{array}$ & Null bypetheses is rejected \\
\hline
\end{tabular}

\begin{tabular}{|c|c|c|}
\hline Satistical teet & Saristixal resals & Conclusiona \\
\hline Ose ray-ANOWA & $\begin{array}{l}\text { Welch } \\
p=0,00\end{array}$ & Noll hypotbeves is rejected \\
\hline
\end{tabular}

University affiliated institutes in Mumbai and Pune.

Thus Managerial skills development in Autonomous institutes of Pune and Mumbai is better than University affiliated institutes of Mumbai and Pune .

Thus the hypothesis is tested and proved.

\section{Findings :}

Data Analysis was done in total four groups of institutes (Autonomous institutes of Pune, University affiliated institutes of Pune, Autonomous institutes of Mumbai and University affiliated institutes of Mumbai ).

Finding are written in two groups, whenever same findings are noted in similar types of institutes .(Autonomous Institutes and University affiliated Institutes) .

Rest of the findings is written with reference to all four types of Institutes.

\section{FINDINGS OF DATA ANALYSIS FOR STUDENTS}

1. It has been observed that students from Commerce and science background give more preference to MBA than Arts and engineering graduates.

2. Maximum number of students have registered for finance and then marketing less number of students have registered for HRM and other subjects for specialization

3. Maximum number of students have no work experience and around $33 \%$ students have got work experience before taking admission to MBA .

4. Placements, value addition and to acquire professional skills or competencies -These three parameters are given equal importance by students for taking admission to MBA course in Autonomous Institutes as well as University affiliated Institutes.

5. Students of Autonomous institutes are exposed equally to all five types of curricular activities.

6. Students of University affiliated Institutes of Pune are exposed almost equally to all five types of curricular activities. University affiliated Institutes of Mumbai focus more on Industry visits, guest lectures, workshops and seminars by industry people .Sponsorship for events and summer projects are given less weightage .

7. Autonomous institutes of Pune give almost equal importance to all five types of activities for internal assessment.

8. Students of University affiliated institutes in Pune are exposed more on tutorials, internal examination and physical attendance .Class preparation and extracurricular activities are given less weightage.

9. Autonomous institutes in Mumbai focus more to internal examination, physical attendance and tutorials. Extracurricular activities and class preparation are given less weightage .

10. Students of University affiliated institutes in Mumbai focus more on physical attendance, tutorials, and extracurricular activities. Class preparation and tutorials are given less weightage . 
11. Internal assessment method is used more effectively by Autonomous Institutes in Pune than other three types of institutes. project is conducted more effectively in Autonomous institutes of Pune compared to other three types of institutes.

12. Major development in personality is seen in MBA students of Autonomous institutes than students of University affiliated institutes.

13. Learning outcomes are better in students of Autonomous institutes than students of University affiliated institutes.

14. It was observed that there is more improvement in skills and abilities of students of Autonomous institutes compared to students of University affiliated Institutes .

15. Autonomous institutes have done comparatively better than University affiliated institutes in Industry -Institute Partnership.

16. Students perception of regarding course in teaching methodology is better in Autonomous institutes than in University affiliated institutes.

17. Students perception of faculty competence is better in University affiliated institutes in Mumbai, Autonomous institutes of Pune and Mumbai than University affiliated institutes of Pune.

18. Students perception of Competitive environment is better in University affiliated institutes of Mumbai, Autonomous institutes of Pune and Mumbai as compared to University affiliated institutes of Pune.

19. Students perception of quality of programmes is better in Autonomous institutes than in University affiliated institutes.

20. It was observed that scheduling of institutes is more flexible in Autonomous institutes of Pune than University affiliated institutes of Pune and Mumbai and Autonomous institutes of Mumbai.

21. It was observed that Autonomous institutes of Pune pay more personal attention to students than University affiliated institutes of Pune and Mumbai and Autonomous institutes of Mumbai .

22. Autonomous institutes of Mumbai prefer more for accommodation of working students than Autonomous institutes of Pune, University affiliated institutes of Pune and Mumbai.

23. There are more faculty member with real world experience in Autonomous institutes compared to University affiliated institutes.

24. Networking ties in business community is better in Autonomous institutes of Pune than Autonomous institutes of Mumbai, University affiliated institutes of Pune and Mumbai.

25. It was observed that Communication skills development is better in students of Autonomous institutes of Pune and Mumbai and University affiliated institutes of Mumbai than University affiliated in Pune.

26. Motivation skills development is better in students of Autonomous institutes than students of University affiliated institutes.

27. Analytical and logical skills development is
Also course in research methodology before research

better in students of University affiliated institutes than students of Autonomous institutes.

28. Crisis management skills development is better in students of Autonomous institutes than University affiliated institutes.

29. Leadership skills development is better in students of Autonomous institutes than students of University affiliated institutes.

30. Innovative skills development is better in students of Autonomous institutes of Pune than Autonomous institutes of Mumbai, University affiliated institutes of Mumbai and Pune .

31. Decision making skills development is better in students of Autonomous institutes of Mumbai than Autonomous institutes of Pune, University affiliated institutes of Pune and Mumbai .

\section{FINDINGS OF DATA ANALYSIS FOR FACULTY MEMBERS}

1. Proportion of full time faculty members is more in University affiliated institutes of Pune and Autonomous institutes of Mumbai compared to University affiliated institutes of Mumbai and Autonomous institutes of Pune

2. According to faculty members perception of learning outcomes, Autonomous institutes of Pune focus more on acquiring domain knowledge and reading and learning initiatives while upgrading teaching skills, research and research skills are given less weightage.

3. University affiliated institutes of Pune focus more on research and acquiring domain knowledge in learning initiatives .Reading, upgrading teaching skills and research skills are given less weightage.

4. Autonomous institutes of Mumbai focus more on research and acquiring domain knowledge in learning initiatives .Reading , upgrading teaching skills and research skills are given less weightage .

5. University affiliated institutes in Mumbai focus more on acquiring domain knowledge and reading in learning initiatives .Upgrading teaching skills, research and research skills are given less weightage .

6. Autonomous institutes of Pune focus more on test and assignments, compelling students to analyse cases, exposing students to the realities of the field, encouragement of students to read a lot ,supply students with lots of information etc. in the students development initiatives undertaken by faculty members . Compelling students to write research papers, building analytical skills and organizing events are given less weightage .

7. University affiliated institutes in Pune focus more on supplying students with lots of information, test and assignments, often comforting students with test and assignments, encouragement of students to read a lot, compelling students to write research papers and building analytical skills in the Students development initiatives undertaken by faculty members. Organizing events, analyzing cases, and exposing students to the realities of 
field are given less weightage

8. Autonomous institutes in Mumbai focus more on supplying students with lots of information, comforting students with tests and assignments, organizing events, encouraging students to read a lot and to analysing cases.

Exposing students to the realities of the field, building analytical skills, and writing research papers are given less weightage.

9. University affiliated institutes in Mumbai focus more on supplying students with lots of information ,often comforting students with test and assignments, to organize events ,to expose students to the realities of the field and to compel students to analyze cases in the students development initiatives undertaken by faculty members .building analytical skills, to compel students to write research papers and to encourage students to read a lot are given less weigtage.

10. Autonomous institutes and University affiliated institutes are able to complete the syllabus in time except for a very few autonomous Institutes.

11. Autonomous and University affiliated institutes conduct extra classes for completion of syllabus.

12. Both Autonomous and University affiliated institutes take part in designing syllabus almost equally, except for few institutes from University affiliated institutes in Mumbai which do not take part in designing syllabus.

13. Autonomous and University affiliated institutes fulfill industry needs except for few from University affiliated institutes in Mumbai.

14. Both Autonomous and University affiliated types of institute's make research articles available for students except for few from university affiliated institutes in Mumbai.

15. Both Autonomous and University affiliated institutes' make audiovisual aids available for students except for few institutes from University affiliated institutes in Mumbai.

16. Faculty members of Autonomous institutes in Pune focus more on case study, group discussion, lectures and role play. Brain storming sessions, team teaching sessions and seminars are given less weigtage.

17. Faculty members of University affiliated institutes in Pune focus more on seminars, brain storming sessions, lectures and group discussions .Team teaching sessions, case study and role play are given less weigtage.

18. Faculty members of Autonomous institutes in Mumbai focus more on seminars, brain storming sessions, lectures and Team teaching sessions. Group discussions, case study and role play are given less weigtage.

19. Faculty members of University affiliated institutes in Mumbai focus more on Group discussions, lectures, Team teaching sessions and role play. Case study, seminars, and brain storming sessions are given less weigtage.

20. Multiple response analysis for various books referred for teaching by faculty members of Autonomous institutes of Pune shows that $50 \%$ faculty member refer books recommended in syllabus and $50 \%$ refer other reference books .In case of faculty members from university affiliated institutes of Pune, 51.2\% refer books recommended in syllabus and $48.8 \%$ faculty members refer other reference books $.46 .3 \%$ Faculty members from Autonomous institutes of Mumbai refer books recommended in syllabus and $53.8 \%$ faculty members refer to other reference books $.64 .2 \%$ Faculty members of University affiliated institutes of Mumbai refer books recommended in syllabus and $35.8 \%$ faculty members refer to other reference books.

21. Faculty members of Autonomous institutes in Mumbai and University affiliated institutes in Pune are more interested in upgrading syllabus than faculty members of Autonomous institutes in Pune and University affiliated institutes in Mumbai.

22. Faculty members of University affiliated institutes are satisfied with students attendance compared to faculty members from Autonomous institutes.

23. Attitudinal change due to industrial visit is seen more in University affiliated institutes in Pune and Autonomous institutes in Mumbai compared to students of university affiliated institutes in Mumbai and Autonomous institutes in Pune.

24. Faculty members of Autonomous institutes in Pune focus more on group discussion, project reports, seminars and semester examination. End examination, class test and vivas are given less weightage.

25. Faculty members of University affiliated institutes in Pune focus more on class test End examination, group discussion and seminars. Semester examination, Project report and viva are given less weightage.

26. Faculty members of Autonomous institutes in Mumbai gives equal importance to all parameters in evaluation system.

27. Faculty members of University affiliated institutes in Mumbai focus more on end examination, class test, and Viva and group discussion. Seminars, semester examination and project reports are given less weigtage.

28. Faculty members of Autonomous institutes are more satisfied with placements of their students but faculty members of University affiliated institutes in Mumbai and Pune are less satisfied with placements of their students.

29. Faculty members of Autonomous institutes in Pune are successful in skill development of students in leadership skill, communication skills , Innovative skills , Measured level of confidence Management skill development, crisis Management skills and Decision making skills . Motivation skills, Personality development, Analytical and logical skills are given less weigtage.

30. Faculty members of University affiliated institutes in Pune are successful in developing crisis Management skills, Analytical logical skills, Decision making skills, Measured level of confidence, Personality development, communication skill development and Motivation skills. Leadership skill development, Management skill 
development, and Innovative skills are given less weightage.

31. Faculty members of Autonomous institutes in Mumbai are successful in developing Management skills development, Innovative skills, Analytical logical skills, communication skill development, measured level of confidence and Leadership skill development. Personality development, Decision making skills ,crisis Management skills and Motivation skills are given less weigtage.

32. University affiliated institutes in Mumbai are successful in developing Innovative skills , crisis Management skills, communication skill development, Personality development, Measured level of confidence ,Motivation skills and Decision making skills. Management skills development, Leadership skill development, Analytical and logical skills are given less weightage .

33. Faculty members of Autonomous institutes in Pune focus more on Lectures on current topics by industry experts , MDPs for Industry , Surveys for Industry and Student career/professional club. FDP by Industry people, work project and Consultancy to the Industry are given less weightage .

34. Faculty members of University affiliated institutes in Pune focus more on Lectures on current topics by industry people, work project, Surveys for Industry and Consultancy to the Industry. Student career/professional club, MDPs for Industry and FDP by Industry people are given less weightage.

35. Faculty members of Autonomous institutes in Mumbai focus more on Consultancy to the Industry, FDP by Industry people, work project and Lectures on current topics by industry people. Student career /professional club, Surveys for Industry and MDPs for Industry are given less weightage.

36. Faculty members of University affiliated institutes in Mumbai focus more on Consultancy to the Industry, FDP by Industry people, Lectures on current topics by industry people and student career /professional club. Surveys for Industry, MDPs for Industry, work project are given less weightage.

37. Autonomous institutes in Mumbai are involved more in course designing and changes in syllabus than University affiliated institutes

\section{CONCLUSION}

The research has been carried out across two categories of Institutes in Pune and Mumbai regions i.e Autonomous Institutes of Pune and Mumbai and Institutes, affiliated to Pune and Mumbai University .The analysis shows that Autonomous Institutes have performed better than University affiliated Institutes .

The performance of Autonomous Institutes was excellent in implementing curricular and co- curricular activities and using internal assessment methods effectively. Autonomous Institutes have focused more on overall growth of students through personality development programmes, learning outcome, improvement of skills and abilities by strengthening Industry -Institute partnership. Autonomous institutes insist more on students attendance, Competitive environment ,quality of
Programmes for students and flexibility of scheduling .These institutes have given weightage for continues evaluation through tutorials and class preparations , summer projects ,and seminars

These institutes are ahead of University affiliated Institutes in faculty members with real world experience, giving personal attention to students .These Institutes carry out various activities for enhancement of Innovative skills, Leadership skills and crisis management skills. All these sum up to give better placements to their students .

Students perception in these institutes regarding teaching methodology, faculty competence, Competitive environment and quality of programmes in Autonomous institutes is found to be very much satisfactory .

Autonomous institutes fail to provide good research platform to their students and faculty members Research platform helps students to explore the new vision and equip themselves for industry exposure .

Autonomous institutes has got upper hand in experienced faculty members and staff to provide competitive environment which gives platform to students to accept challenges and come with solutions as this is the first step of training before entering into industry .

With all these advantages of Autonomous institutes ,Students shows excellent performance in development of Communication skills, decision making skills, Leadership skills, Motivation and innovative skills which ultimately reflects in good attitudinal changes in students of their institutes University affiliated Institutes have tried their level best in providing Competitive environment to students, concentrated on students attendance and also appointing more experienced faculty members which helps in development of Communication skills ,Motivational skills , Logical and analytical skills in students. Implementation of curricular activities like Industrial visits, summer projects, guest lectures in University affiliated institutes is also satisfactory.

But University affiliated institutes are lagging behind Autonomous Institutes in all other parameters like syllabus design ,tie up with industries ,overall development of students, attitudinal change in students, involvement of industries in designing syllabus etc .

Thus Autonomous institutes have shown better performance, on the contrary University affiliated Institutes fall short on many accounts than Autonomous Institutes.

\section{SUGGESTIONS AND RECOMMENDATIONS}

$>$ This research study reveals that, Institutes which have got autonomy for their functioning have improved their quality to great extent .

For example -All premier institutes (IIMs) and Autonomous MBA institutes have got Autonomy regarding changes in syllabi,fee structure etc .and these institutes are able to maintain high standards of education 
The MBA programme is run to bridge the gap between the Industry requirement and fresh graduates. It means that MBA graduate should be partially trained manager before he should enter into the Industry. To fill this gap researcher propose the following suggestions for all levels i.e Students, faculty members, Institute and Government.

\section{For the students :}

$>$ It was observed that students from Arts, Science, commerce and technical background take admission for MBA course. During graduation personality development is not necessary to be the part of their curriculum. But as a manager it is important trait of MBA graduate therefore it is necessary that student should pay more attention towards polishing their personality along with their studies.

$>$ Students interest in research activities is found to be less than expected in all four types of institutes. Research oriented projects and activities are essential to formulate new policies which can benefit all management institutes in future .so focus on research based activities be included as part of MBA curriculum .

$>$ Students should focus on acquiring updated critical \& analytical skills.

$>$ Students should develop their approach as to be "JOB GIVER INSTEAD OF JOB SEEKER"

$>$ Student should read different cases of industries along with solutions and increase their participation in case study, business plan competitions this will help them to improve their problem solving skill \& decision making skills.

\section{For the Faculty members :-}

$>$ MBA programme is basically to create either Managers or businessmen therefore it is of utmost importance that the teachers who teach them must have basic knowledge of these fields.

$>$ Faculty should have the urge to update themselves through industry training. Those faculty who do not have industry exposure must undergo minimum 20 days training during their vacation period to enable themselves to satisfy the need of MBA curriculum. Teaching through reading books may not generate interest among students about the programme.

$>$ Faculty members should actively participate in paper assessment this help the faculty in teaching as they understand the mistakes students are doing while writing papers and what is the gap of learning

$>$ Faculty members should promote specialization forums, clubs in the institute where open discussion on various current issues, new development of ideas should be discussed this helps to improve faculty knowledge.

$>$ Faculty members must try to give consultancy or training to company employees on various topics to enhance the skills and functioning of organization.

\section{For the Institutes:-}

$>$ It is seen that many institutes are lagging behind on and active participation of students in these activities can knowledge through reading news paper, live discussion on current topics which will help them in developing

various parameters such as good teaching staff, infrastructure, and student development. Institute should promote faculty development approach institute which intern will develop students also.

$>$ Institute should focus on Industry-Institute partnership to impart good quality management education. Students \& faculty regular interaction with industry improve the managerial skills in both. Industry experience sharing, guest lectures must be a regular phenomena at institute level for managerial skill enhancement.

$>$ Institute - Industry MOU's is another way to increase the bond between the institute and industry.

$>$ To build better image of professionalism in industry institute must promote the industry participation in various programmes of the institute.

$>$ Institute must invite Industry nominee to frame certain institute level courses.

\section{For the Government:}

$>$ Government policy of granting the permission to new institute should be only after satisfaction of required norms, otherwise it is hampering the image of the MBA degree.

$>$ There should be periodical review of the institute performance and the extension of institute should be permitted.

$>$ The government rule should not be cumbersome in terms of hiring permanent faculty in the institute. MBA is not a regular degree it is a professional degree and you need some professionally experience people too to teach the course. The policy should give some autonomy to the institute to hire the faculty. Hiring ratio should proportionate. Out of total faculty members $70 \%$ faculty must be permanent and $30 \%$ should be visiting. This will ease the institute from economical burden.

$>$ UGC should permit existing management institutes to tie up with industry for some programme or undertake run industry oriented subjects. There industry will train the students as per their requirement.

\section{REFERENCES}

1. Apoorwa Bharadwaj ,Indian Institute of Management Calcutta, India "Globalization in Management Education challenges \& Strategies" - International Journal of Arts and Sciences 3(7) : 466 - 477 (2010) CD-ROM. ISSN: 1944-6934 () InternationalJournal.org .

2. David Finegold, Brent Krentner, "Institutional effects on skill creation.:A comparison of management Development in the U.S. \& Germany", CEO Centre for Effective Organizations, 31st May ,1995.

3. Dr. V. R. Mehta ," "Management Education in the New Millennium"I.I.M. Review vol.3 No.2 April 1999 Quarterly News letter - New Delhi.

4. Anis U.R Rehman, Dr. Yasir Arafat ElahiIntegral university, Lmeknow. "“"Entrepreneurship Education in India - Scope, challenge and Role of B- Schools in promoting .Entrepreneurship Education"., International Journal of Engineering and Management Research Vo12, 

selected Institutes in Pune and Mumbai"

Issue-5, October 2012. (Pages5-14) ISSN No.: 2250-0758.

5. Dr. Bharat Meghe Readee and head dept of commerce, Kamala Nehru College Nagpur.."Business schools in India and Students expectations" International Referred Research Journal ISSN-0974-2832 VOL. I * ISSUE-17 RNI : RAJBIL/2009/29954.

6. Bholanath Datta , "Management of management Department A road to excellence', pg no105-156.

7. Sonal Bhat, Dr Pratibha Joshi , "Industry Institute Interaction :A stakeholder Perspective " Novel Research Kaleidoscope ,Pg no 66-80 vol no 4Feb 2014.

8. Manzoor shah "Management Education : Challenges and future directions ' University news, Vol 50 no 48 26th November -2 nd December 2012.

9. Abhijit Bora , "Professional Education : Overcoming Major Challenges", University News ,49(52)December26,2011-01January,2012 Pg no 9-13.

10. Ankush More ,(2012) Management Education : Recent Trends, Challenges and Opportunities, Univresity news ,50 (06) February 06-12, 2012 Pg no 17-24. 